\title{
Corrosion Effect on Flexural Mechanical Property of Concrete Reinforcement Steel in Corrosive Environment
}

\author{
Charles Kennedy $^{1}$, Ukeamezhim Chimezie Festus ${ }^{2}$, Daso Dokibo ${ }^{3}$ \\ ${ }^{1}$ Faculty of Engineering, Department of Civil Engineering, Rivers State University, Nkpolu. \\ Port Harcourt, Nigeria. \\ ${ }^{2,3}$ School of Engineering, Department of Civil Engineering, Kenule Beeson Saro-Wiwa \\ Polytechnic, Bori, Rivers State, Nigeria. \\ E-mail: ${ }^{1}$ ken_charl@yahoo.co.uk, ${ }^{2}$ drucfestus@gmail.com, ${ }^{3}$ mori7real@yahoo.com
}

ABSTRACT
The corrosion of steel bars in concrete is affected by wide range of parameters such as waterto-cement ratio, permeability, concrete cover, crack width and the use of supplementary cementitious materials. The research work evaluated the flexural behavior of reinforcing (reinforcement) steel of non-coated and coated specimens with acacia senegal exudates/resins of varying coated thickness embedded in concrete beam, immersed in corrosive media and accelerated for 150 days. Obtained results after accelerated duration confirmed non-coated specimen with corrosion potential attributes of cracks and spalling. Averaged derived flexural failure load values of corroded samples percentile difference of $-32.0242 \%$ against $27.96875 \%$ and 46.7759 against non-corroded and acacia senegal exudates coated specimens. Midspan deflection averaged value percentile difference of $77.89474 \%$ against $-43.787 \%$ and $-44.8743 \%$ controlled and coated specimens. Average yield strength, $460 \mathrm{MPa}$, summed up to $100 \%$ with $0.00 \%$ of percentile value and difference. Averaged ultimate tensile strength, percentile difference of $-10.2433 \%$ against $11.41226 \%$ and 11.41226 of non-corroded and coated specimens. Averaged strain ratios percentile difference values of $-10.9478 \%$ against $12.29364 \%$ and $12.82435 \%$ of non-corroded and coated specimens. Averaged elongations percentile difference values of $-41.8705 \%$ against $72.02975 \%$ and $70.21979 \%$ for noncorroded and coated specimens. Summarized results of corroded showed and exhibited high flexural failure loads against non-corroded and coated specimens, midspan deflection rates are higher to non-corroded and coated specimens, ultimate tensile strength of corroded specimens are all higher to non-corrode and coated specimens. Overall experimental tests showed that mechanical properties of reinforcing steel are adversely affected by the presence corrosion.

Key Words: Corrosion, Corrosion inhibitors, Pull-out Bond Strength, Concrete and Steel Reinforcement

\section{INTRODUCTION}

Corrosion of reinforcing steel in concrete structure assumes many forms and their product results occur when there is chemical reaction between metal and its environment. Rust products form on the bar, expanding its volume and creating stress in the surrounding concrete causing cracking, spalling and staining of concrete, and reduce the effective crosssectional area of reinforcing bars, thereby having less load carrying capacity. The corrosion of steel bars in concrete is affected by a wide range of parameters such as water-to-cement ratio, permeability, concrete cover, crack width and the use of supplementary cementitious materials. 
[1] Stated that bonding is more likely to affect structural capacity than is loss of tensile strength of reinforcement resulting from general corrosion. Experiment results indicated that the level of reinforcement corrosion does not influence the tensile strength of steel bars (calculated on the actual area of cross-section), but reinforcing steel bars with more than $12 \%$ corrosion indicates a brittle failure.

[2] Concluded that the strength ratio and elastic modulus of reinforcement are not significantly affected by corrosion and consequently the strength and modulus of elasticity of non-corroded bars can be adopted in practice.

[3] Investigated the residual yield strength structural capacity effect of non-corroded, corroded and inhibited steel bar. The results of coated steel bar with three different resins / exudates extracts of Symphonia globulifera linn, ficus glumosa and acardium occidentale 1.) versus corroded on comparison, the flexural strength failure load are 29.50\%, 28.505,29.57\% against $22.30 \%$ corroded, midspan deflection are $31.14 \%, 25.30 \%, 22.30 \%$ against 39,30\% corroded, tensile strength $11.84 \%, 12.13 \%, 12.14 \%$ against $10.17 \%$ and elongation are $32.40 \%, 32.13 \%, 32.40 \%$ against $46.30 \%$ corroded. Overall results indicated that coated steel bar showed higher values increased in failure load and tensile strength while corroded decreased in elongation and midspan deflection.

[4] Investigated the flexural action of combined effect of corrosion and sustained loads of reinforced concrete corroded beams. Test results showed that the presence of a sustained load and associated flexural cracks during corrosion exposure significantly reduced the time to corrosion cracking and slightly increased the corrosion crack width. They found that crack width would propagate $22 \%$ faster in loaded conditions, observed that with $8.9 \%$ and $22.2 \%$ mass loss, strength losses of $6.4 \%$ and $20.0 \%$ respectively

[5] Investigated the effect on flexural residual yield strength capacity of three different resins/exudates extract of trees of dacryodes edulis, moringa oleifera lam, mangifera indica paste coated reinforcement on the concrete beam. Flexural strength failure loads of coated members with dacryodes edulis, moringa oleifera lam, mangifera indica are $35.78 \%, 27.09 \%$, $29.42 \%$ against $22.30 \%$ decreased in corroded, midspan deflection are $18.57 \%, 28.30 \%$, $27.43 \%$ against $39.30 \%$ increased in corroded, elongation are $28.75 \%, 31.50 \%, 31.60$ against $46.30 \%$ increased in corroded and tensile strength are $14.18 \%, 12.29 \%, 12.08 \%$ as against $10.17 \%$ decreased in corroded respectively. Entire results showed that low load subjection is recorded in coated members at failure loads as against in corroded with high deflection and elongation.

[6] Investigated the flexural capacity loss with steel cross-sectional loss due generalized corrosion of embedded steel using specimens of concrete beams with $100 \mathrm{~mm} \times 150 \mathrm{~mm}$ cross section and $1500 \mathrm{~mm}$ in length cast with chlorides. The specimens were tested in flexure under three point loading. They concluded that flexural load capacity decreased by $60 \%$ with only $10 \%$ ratio, the most important parameter affecting flexural load capacity reduction, because pitting corrosion greatly decrease the cross sectional area of the steel at a certain location and change the steel from ductile behavior to brittle behavior.

[7] Examined the effect/impact of corrosion inhibitors on flexural strength of failure load, midspan deflection, tensile strength and elongation of steel reinforcement layered with resins/exudates of magnifera indica extracts as corrosion inhibitors. More results recorded on experimental work showed flexural strength failure load, midspan deflection, tensile strength 
and elongation as $29.09 \%, 31.20 \%, 11.75 \%$ and $31.50 \%$ for non-corroded, $29.42 \%, 27.43 \%$, $12.09 \%$ and $31.60 \%$ for coated concrete beam respectively. Entire results showed the effect of corrosion on the flexural strength of reinforcement that led to low load on failure load and higher midspan deflection on corroded beams and flexural load on failure load and low midspan deflection on non-corroded and coated concrete beam members resulting to attack on surface condition of reinforcement from corrosion.

[8] Investigative study was carried out to ascertain the utilization of natural inorganic extracts of tree resin/exudates to assess the yield strength capacity of reinforced concrete beam members under corrosion accelerated medium. resins/exudates pasted of thickness ranges of $150 \mu \mathrm{m}, 250 \mu \mathrm{m}$ and $350 \mu \mathrm{m}$ were directly coated on steel bar, embedded into concrete and performed corrosion acceleration process performed on both uncoated and coated reinforced concrete members. Non - corroded and coated members in comparison with corroded recorded increasing values on flexural strength failure load by $23.8 \%$ and $29.59 \%$ against $22.30 \%$ of corroded, tensile strength non - corroded and coated increased by $12.03 \%$, $12.14 \%$ over $10.17 \%$ of corroded while decreasing values on midspan deflection of $28.30 \%$ and $22.30 \%$, elongation $31.5 \%$ and $32.46 \%$ recorded on non-corroded and coated concrete beam members as against $39.30 \%$ and $46.30 \%$ of corroded respectively.

[9] Investigated the effects of corrosion on the residual structural steel bar capacity of resins/exudates inhibited and non-inhibited reinforced concrete beam members. Steel reinforcements were coated with moringa oleifera lam resins/exudates from trees extract (Inorganic inhibitors), embedded into concrete beam members and exposed to sodium chloride medium representing laboratory harsh saline marine environment. Further recorded results on non-corroded flexural strength test of failure load $29.09 \%$, midspan deflection $28.30 \%$, tensile strength $12.03 \%$ and elongation $31.50 \%$, for coated beam members, failure load $29.42 \%$, midspan deflection $27.42 \%$, tensile strength $12.09 \%$ and elongation $31.80 \%$, for corroded beam members, failure load decreased by $22.50 \%$, midspan deflection increased by $39.30 \%$, tensile strength decreased to $10.17 \%$ and elongation by increased $46.30 \%$.

[10] investigated the effect of corrosion on the flexural strength and mid-span deflection of steel reinforcements coated with resins / exudates of trees extract known as inorganic inhibitors (dacryodes edulis-African Pear). Corrosion accelerated test were conducted on uncoated and dacryodes edulis resin pastes coated thicknesses of $150 \mu \mathrm{m}, 250 \mu \mathrm{m}$ and $300 \mu \mathrm{m}$ on steel reinforcement before corrosion test for 60 days to simulated corrosion process. Results obtained indicated that the flexural failure strength, and elongation increased by $(29 \%)$ and $(48 \%)$ respectively for the dacryodes edulis coated steel members, the mid-span deflection decreased by $26 \%$, elongation increased by $23 \%$ and $32 \%$ respectively, while the mid-span deflection decreased by $40 \%$. The resin (dacryodes edulis) added strength to the reinforcement.

[11] experimented on the effects of corrosion and inhibitors (Inorganic origin) extracts known as resins/exudates from trees barks on the residual flexural strength of concrete beam members immersed in corrosion accelerated medium for 90 days to ascertain possible changes on surface conditions of investigated samples. Further results obtained of corroded concrete beam members were $22,50 \%, 39.30 \%, 10.19 \%$ and 46.30 of failure load, midspan deflection, ultimate tensile strength and elongation, for non- $29.09 \%, 28.30 \%, 12.03 \%$ and $31.50 \%$, for coated beam members , $28.5 \%, 25.30 \%, 12.13 \%$ and $32.12 \%$ respectively. This showed lower load and higher deflection in corroded members and higher in non-corroded and coated, higher elongation in corroded and lower in non-corroded and coated. 


\section{MATERIALS AND METHODS FOR EXPERINMENT}

\section{Aggregates}

The fine aggregate and coarse aggregate were purchased. Both met the requirements of [12].

\section{Cement}

Portland limestone cement grade 42.5 is the most and commonly type of cement in Nigerian

Market. It was used for all concrete mixes in this investigation. The cement met the requirements of [13].

\section{Water}

The water samples were clean and free from impurities. The fresh water used was gotten from the tap at the Civil Engineering Department Laboratory, Kenule Beeson Polytechnic, Bori, and Rivers State. The water met the requirements of [14].

\section{Structural Steel Reinforcement}

The reinforcements are gotten directly from the market in Port Harcourt and met the requirements [15]

\section{Corrosion Inhibitors (Resins / Exudates) Acacia senegal}

The study inhibitor (Acacia senegal exudates) of natural tree resins/exudates extracts.

\section{Methods}

Present study involves direct application of resins / exudates of trees extract known as inorganic inhibitor acacia Senegal exudates), layered/coated on reinforcement steel ribbed surface.

The samples of reinforced concrete beams of $150 \mathrm{~mm} \times 150 \mathrm{~mm} \times 750 \mathrm{~mm}$, thickness, width and length specimens and ribbed bars of $16 \mathrm{~mm}$ embedded for corrosion test and flexural test for beam was investigated. This was aimed at achieving the real harsh and corrosive state, concrete specimens were ponded in solutions $(\mathrm{NaCl})$ and the depth of the solution was maintained for the given period of experiment as to observe the significant changes that resulted from the actions of the accelerator $(\mathrm{NaCl})$ and the specimens.

\section{Specimen Preparation and Casting of Concrete Beams}

Standard method of concrete mix ratio was adopted, batching by weighing materials manually. Concrete mix ratio of $1: 2: 4$ by weight of concrete, water-cement ratio of 0.65 . Manual mixing was used on a clean concrete banker, and mixture was monitored and water added gradually to obtain perfect mix design concrete. Standard uniform color and consistency concrete was obtained by additions of cement, water and aggregates. The test beams were cast in steel mould of $150 \mathrm{~mm}$ x $150 \mathrm{~mm}$ x $750 \mathrm{~mm}$. Fresh concrete mix for each batch was fully compacted by tamping rods, to remove trapped air, which can reduce the strength of the concrete and $16 \mathrm{~mm}$ reinforcements of coated and non-coated were spaced at $150 \mathrm{~mm}$ with concrete cover of $25 \mathrm{~mm}$ had been embedded inside the beam and projection of $100 \mathrm{~mm}$ for half-cell potential measurement. Specimens were molds are removed from specimen after $24 \mathrm{hrs}$ and cured for 28 days. The specimens were cured at room temperature in the curing tanks for accelerated corrosion test process and testing procedure allowed for 120 days first crack noticed and a further 30 days making a total of 150 days for further observations on corrosion acceleration process.

\section{Flexure testing of Beam Specimens}

Universal Testing Machine in accordance with BS EN 12390-2 was used for the flexural test and a total of 27 beam specimens were tested. After curing for 28 days, 6 controlled beams (non-corroded) was kept in a control state, preventing corrosion of reinforcement, while 18 beam samples of non-coated and exudates /resins coated were partially place in ponding tank for 150 days and examined accelerated corrosion process. An Instron Universal Testing Machine of $100 \mathrm{KN}$ capacity at a slow loading rate of $1 \mathrm{~mm} / \mathrm{min}$ was used in the flexural test. 
Beam samples were placed in the machine to specification, flexural test were conducted on a third point at two supports.

\section{Tensile Strength of Reinforcing Bars}

To ascertain the yield and tensile strength of tension bars, bar specimens of $16 \mathrm{~mm}$ diameter of non-corroded, corroded and coated were tested in tension in a Universal Testing Machine and subjected to direct tension until failure; the yield, maximum and failure loads being recorded. To ensure consistency, the remaining cut pieces from the standard length of corroded and non-corroded steel bars were subsequently used in the bond and flexural test.

\section{RESULTS AND DISCUSSIONS}

Results of 27 samples in table 1, 2 and 3 are derived into averaged values in 4 and summarized into summary of averages, percentile values and percentile values difference in 3.5 of flexural strength of concrete beam members as sampled, arbitrarily cast, cured for 28 days on normal and standard method, accelerated in corrosion medium environment for 120days at first cracks observation and 30days extended period and graphically represented in fig. 1 - 3.

\section{Non-corroded Concrete Beam Members}

Averaged derived flexural failure load values of non-corroded samples are $80.37 \mathrm{kN}$, $80.25667 \mathrm{kN}, 80.72667 \mathrm{kN}$, summed up to $80.45111 \mathrm{kN}$ with percentile difference of $27.96875 \%$ over $-32.0242 \%$ corroded specimens. Midspan deflection average values are $6.603333 \mathrm{~mm}, 6.846667 \mathrm{~mm}, 6.306667 \mathrm{~mm}$, summed up to $6.585556 \mathrm{~mm}$ with percentile difference of $-43.787 \%$ over $77.89474 \%$ corroded specimens. Average yield strength, $460 \mathrm{MPa}$, summed up to $100 \%$ with $0.00 \%$ of percentile value and difference, Average ultimate tensile strength, fu, 632.6833MPa, 632.4167MPa, and $632.1167 \mathrm{MPa}$, summed up to $632.4056 \mathrm{MPa}$, percentile difference of $11.41226 \%$ over $-10.2433 \%$ corroded specimens. Average strain ratios are $1.311667,1.315$, and 1.305 , summed up to 1.305 with percentile difference values of $12.29364 \%$ over $-10.9478 \%$. Averaged elongations are $28.6055 \%$, $28.6055 \%, 28.72883 \%$, summed up to $28.55439 \%$ with percentile difference values of $72.02975 \%$ over $-41.8705 \%$. Summarized results of non-corroded over corroded specimens showed that non-corroded ( controlled) samples superseded corroded samples properties in low flexural failure, low midspan - deflection, normal yield strength, high ultimate strength, low strain ratio.

\section{Corroded Concrete Beam members}

Averaged derived flexural failure load values of corroded samples are $63.543333 \mathrm{kN}$, $62.490 \mathrm{kN}, 62.570 \mathrm{kN}$, summed up to $67.97583 \mathrm{kN}$ with percentile difference of $-32.0242 \%$ over $27.96875 \%$ and 46.7759 against non-corroded and acacia senegal exudates coated specimens. Midspan deflection average values are $13.133333 \mathrm{~mm}, 12.833333 \mathrm{~mm}$, $12.78667 \mathrm{~mm}$, summed up to $12.91778 \mathrm{~mm}$ with and percentile difference of $77.89474 \%$ against $-43.787 \%$ and $-44.8743 \%$ controlled and coated specimens. Average yield strength, $460 \mathrm{MPa}$, summed up to $100 \%$ with $0.00 \%$ of percentile value and difference. Average ultimate tensile strength, fu, 556.28333MPa, 554.75MPa, 554.8833MPa, summed up to $555.3056 \mathrm{MPa}$, percentile difference of $-10.2433 \%$ against $11.41226 \%$ and 11.41226 of noncorroded and coated specimens. Average strain ratios are 1.1583333, 1.165, and 1.148333, summed up to 1.157222 with percentile difference values of $-10.9478 \%$ against $12.29364 \%$ and $12.82435 \%$ of non-corroded and coated specimens. Averaged elongations are $14.643333 \%, 14.423333 \%, 14.60333 \%$, summed up to $14.55667 \%$ with percentile difference values of $-41.8705 \%$ against $72.02975 \%$ and $70.21979 \%$ for non-corroded and coated specimens. Summarized results of corroded showed and exhibited high flexural failure loads 
over non-corroded and coated specimens, midspan deflection rates are higher to non-corroded and coated specimens, ultimate tensile strength of corroded specimens are all higher to noncorrode and coated specimens. Overall experimental tests showed that mechanical properties of steel reinforcing steel are adversely affected by corrosion presence.

\section{Acacia Senegal Resins/Exudates Steel Coated Concrete Beam Members.}

Averaged derived flexural failure load values of coated samples are $80.320667 \mathrm{kN}$, $80.427333 \mathrm{kN}, 80.39733 \mathrm{kN}$, summed up to $80.38178 \mathrm{kN}$ with percentile difference of 46.7759 over $-32.0242 \%$ over corroded specimens. Midspan deflection average values are $6.5966667 \mathrm{~mm}, 6.6533333 \mathrm{~mm}, 6.636667 \mathrm{~mm}$, summed up to $6.628889 \mathrm{~mm}$ with and percentile difference of $-44.8743 \%$ over $77.89474 \%$ corroded specimens. Average yield strength, $460 \mathrm{MPa}$, summed up to $100 \%$ with $0.00 \%$ of percentile value and difference. Average ultimate tensile strength, fu, $629.5167 \mathrm{MPa}, 629.550 \mathrm{MPa}, 629.4833 \mathrm{MPa}$, summed up to $629.5167 \mathrm{MPa}$, percentile difference of $11.41226 \%$ over $-10.2433 \%$ corroded specimens. Average strain ratios are $1.325167,1.3085$, and 1.315167 , summed up to 1.316278 with percentile difference values of $-12.82435 \%$ over $-10.9478 \%$ of corroded specimens. Averaged elongations are $26.4785 \%, 26.53517 \%, 26.47517 \%$, summed up to $26.49628 \%$ with percentile difference values of $70.21979 \%$ over $-41.8705 \%$ of corroded specimens. Summarized results coated specimens showed low flexural failure load, midspan deflection, strain ratio and ultimate tensile strength. The overall indications of tested specimens clearly showed that that coated exudates to reinforcing steels proved to be inhibitory to corrosion effects.

Table 1. Flexural Strength of Beam Specimens (Non-Corroded specimens)

\begin{tabular}{|c|c|c|c|c|c|c|c|c|c|c|}
\hline s/no & \multicolumn{9}{|c|}{ Non-corroded Control Beam } \\
\hline Beam & Samples & GAK & GBK & GCK & GDK & GEK & GFK & GGK & GHK & GIK \\
\hline $\begin{array}{c}\text { GBG1- } \\
1\end{array}$ & $\begin{array}{c}\text { Failure } \\
\text { Load (KN) }\end{array}$ & 80.43 & 80.43 & 80.25 & 80.22 & 80.22 & 80.33 & 81.03 & 80 & 81.15 \\
\hline $\begin{array}{c}\text { GBG1- } \\
2\end{array}$ & $\begin{array}{c}\text { Midspan } \\
\text { Deflection } \\
\text { (mm) }\end{array}$ & 6.35 & 6.43 & 7.03 & 7.14 & 6.23 & 7.17 & 6.26 & 6.43 & 6.23 \\
\hline $\begin{array}{c}\text { GBG1- } \\
3\end{array}$ & $\begin{array}{c}\text { Bar } \\
\text { diameter } \\
\text { (mm) }\end{array}$ \\
$\begin{array}{c}\text { GBG1- } \\
4\end{array}$ & $\begin{array}{c}\text { Yield } \\
\text { Strength, } \\
\text { fy (MPa) }\end{array}$ & 460 & 460 & 460 & 460 & 460 & 460 & 460 & 460 & 460 \\
\hline $\begin{array}{c}\text { GBG1- } \\
5\end{array}$ & $\begin{array}{c}\text { Ultimate } \\
\text { Tensile } \\
\text { Strength, } \\
\text { fu (MPa) }\end{array}$ & 631.85 & 633.75 & 632.45 & 631.25 & 633.75 & 632.25 & 632.05 & 632.85 & 631.45 \\
\hline $\begin{array}{c}\text { GBG1- } \\
6\end{array}$ & $\begin{array}{c}\text { Strain } \\
\text { Ratio }\end{array}$ & 1.335 & 1.295 & 1.305 & 1.335 & 1.305 & 1.305 & 1.305 & 1.295 & 1.315 \\
\hline $\begin{array}{c}\text { GBG1- } \\
7\end{array}$ & $\begin{array}{c}\text { Elongation } \\
\text { (\%) }\end{array}$ & 28.5055 & 28.7055 & 28.6055 & 28.6755 & 28.1055 & 28.2055 & 28.7055 & 28.6755 & 28.8055 \\
\hline
\end{tabular}




\section{Table 2. Flexural Strength of Beam Specimen (Corroded specimens)}

\begin{tabular}{|c|c|c|c|c|c|c|c|c|c|c|}
\hline s/no & & \multicolumn{9}{|c|}{ Corroded Beam } \\
\hline Beam & Samples & GAK1 & GBK1 & GCK1 & GDK1 & GEK1 & GFK1 & GGK1 & GHK1 & GIK1 \\
\hline GBG2-1 & $\begin{array}{l}\text { Failure load } \\
(\mathrm{KN})\end{array}$ & 63.9 & 64.58 & 62.15 & 61.63 & 63.92 & 61.92 & 61.69 & 64.12 & 61.9 \\
\hline GBG2-2 & $\begin{array}{l}\text { Midspan } \\
\text { Deflection } \\
(\mathrm{mm})\end{array}$ & 13.37 & 13.2 & 12.83 & 12.8 & 12.4 & 13.3 & 12.83 & 12.43 & 13.1 \\
\hline GBG2-3 & $\begin{array}{c}\text { Bar } \\
\text { diameter } \\
(\mathrm{mm})\end{array}$ & 16 & 16 & 16 & 16 & 16 & 16 & 16 & 16 & 16 \\
\hline GBG2-4 & $\begin{array}{l}\text { Yield } \\
\text { Strength, fy } \\
\text { (MPa) }\end{array}$ & 460 & 460 & 460 & 460 & 460 & 460 & 460 & 460 & 460 \\
\hline GBG2-5 & $\begin{array}{c}\text { Ultimate } \\
\text { Tensile } \\
\text { Strength, fu } \\
\text { (MPa) }\end{array}$ & 558.35 & 554.95 & 555.55 & 554.85 & 554.55 & 554.85 & 554.25 & 555.55 & 554.85 \\
\hline GBG2-6 & Strain Ratio & 1.165 & 1.155 & 1.155 & 1.195 & 1.145 & 1.155 & 1.155 & 1.145 & 1.145 \\
\hline GBG2-7 & $\begin{array}{c}\text { Elongation } \\
(\%)\end{array}$ & 14.66 & 14.8 & 14.47 & 14 & 14.99 & 14.28 & 14.8 & 14.5 & 14.51 \\
\hline
\end{tabular}

Table 3. Flexural Strength of Beam Specimens (Exudates/Resins Coated specimens)

\begin{tabular}{|c|c|c|c|c|c|c|c|c|c|c|}
\hline & & \multicolumn{9}{|c|}{ Acacia senegal Exudates ( steel bar coated specimen) } \\
\hline s/no & & \multicolumn{3}{|c|}{$\begin{array}{l}150 \mu \mathrm{m}(\text { Exudate/Resin) } \\
\text { coated }\end{array}$} & \multicolumn{3}{|c|}{$\begin{array}{c}300 \mu \mathrm{m} \text { (Exudate/Resin) } \\
\text { coated }\end{array}$} & \multicolumn{3}{|c|}{$\begin{array}{c}450 \mu m \text { (Exudate/Resin) } \\
\text { coated }\end{array}$} \\
\hline Beam & Samples & GAK2 & GBK2 & GCK2 & GDK1 & GEK2 & GFK2 & GGK2 & GHK2 & GIK2 \\
\hline GBG3-1 & $\begin{array}{c}\text { Failure } \\
\text { load }(\mathrm{KN})\end{array}$ & 79.904 & 80.854 & 80.204 & 80.244 & 80.604 & 80.434 & 80.204 & 80.244 & 80.744 \\
\hline GBG3-2 & $\begin{array}{l}\text { Midspan } \\
\text { Deflection } \\
(\mathrm{mm})\end{array}$ & 6.7 & 6.1 & 6.99 & 6.8 & 6.36 & 6.8 & 6.78 & 6.78 & 6.35 \\
\hline GBG3-3 & $\begin{array}{c}\text { Bar } \\
\text { diameter } \\
(\mathrm{mm})\end{array}$ & 16 & 16 & 16 & 16 & 16 & 16 & 16 & 16 & 16 \\
\hline GBG3-4 & $\begin{array}{c}\text { Yield } \\
\text { Strength, } \\
\text { fy }(\mathrm{MPa})\end{array}$ & 460 & 460 & 460 & 460 & 460 & 460 & 460 & 460 & 460 \\
\hline $\begin{array}{l}\text { GBGE- } \\
5\end{array}$ & $\begin{array}{l}\text { Ultimate } \\
\text { Tensile } \\
\text { Strength, } \\
\text { fu (MPa) }\end{array}$ & 629.05 & 629.95 & 629.55 & 629.55 & 629.55 & 629.55 & 629.15 & 629.65 & 629.65 \\
\hline GBG3-6 & $\begin{array}{l}\text { Strain } \\
\text { Ratio }\end{array}$ & 1.3185 & 1.3385 & 1.3185 & 1.3085 & 1.3085 & 1.3085 & 1.2985 & 1.3185 & 1.3285 \\
\hline GBG3-7 & $\begin{array}{c}\text { Elongation } \\
(\%)\end{array}$ & 26.2385 & 26.8585 & 26.3385 & 26.3085 & 26.7585 & 26.5385 & 26.4485 & 26.1585 & 26.8185 \\
\hline
\end{tabular}


Table 4. Average Flexural Strength of Beam Specimens (Non-Corroded, Corroded

Exudates/Resins Coated Specimens)

\begin{tabular}{|c|c|c|c|c|c|c|c|c|c|c|}
\hline s/no & Samples & $\begin{array}{l}\text { Non-Cor } \\
\text { Average }\end{array}$ & $\begin{array}{l}\text { oded Spe } \\
\text { Jalues }\end{array}$ & mens & $\begin{array}{l}\text { Corrodec } \\
\text { Values }\end{array}$ & Specimens & verage & $\begin{array}{l}\text { Coated S } \\
\text { Values }\end{array}$ & cimens A & rage \\
\hline GBG4-1 & $\begin{array}{l}\text { Failure } \\
\text { load (KN) }\end{array}$ & 80.37 & 80.25667 & 80.72667 & 63.543333 & 62.49 & 62.57 & 80.320667 & 80.427333 & 80.39733 \\
\hline GBG4-2 & $\begin{array}{l}\text { Midspan } \\
\text { Deflection } \\
(\mathrm{mm})\end{array}$ & 6.603333 & 6.846667 & 6.306667 & 13.133333 & 12.833333 & 12.78667 & 6.5966667 & 6.6533333 & 6.636667 \\
\hline GBG4-3 & $\begin{array}{l}\text { Bar } \\
\text { diameter } \\
(\mathrm{mm})\end{array}$ & 16 & 16 & 16 & 16 & 16 & 16 & 16 & 16 & 16 \\
\hline GBG4-4 & $\begin{array}{l}\text { Yield } \\
\text { Strength, } \\
\text { fy (MPa) }\end{array}$ & 460 & 460 & 460 & 460 & 460 & 460 & 460 & 460 & 460 \\
\hline GBG4-5 & $\begin{array}{l}\text { Utimate } \\
\text { Tensile } \\
\text { Strength, } \\
\text { fu (MPa) }\end{array}$ & 632.6833 & 632.4167 & 632.1167 & 556.28333 & 554.75 & 554.8833 & 629.5167 & 629.55 & 629.4833 \\
\hline GBG4-6 & $\begin{array}{l}\text { Strain } \\
\text { Ratio }\end{array}$ & 1.311667 & 1.315 & 1.305 & 1.1583333 & 1.165 & 1.148333 & 1.325167 & 1.3085 & 1.315167 \\
\hline GBG4-7 & $\begin{array}{l}\text { Elongation } \\
(\%)\end{array}$ & 28.6055 & 28.32883 & 28.72883 & 14.643333 & 14.423333 & 14.60333 & 26.4785 & 26.53517 & 26.47517 \\
\hline
\end{tabular}

Table 5. Summary of Percentile Flexural Strength of Beam Specimens (Non-Corroded,

Corroded, Exudates/Resins Coated Specimens)

\begin{tabular}{|c|c|c|c|c|c|c|c|c|c|c|}
\hline Beam & Samples & \multicolumn{3}{|c|}{ Summary of Averages } & \multicolumn{3}{|c|}{ Percentile Values } & \multicolumn{3}{|c|}{ Percentile Difference } \\
\hline GBG5-1 & $\begin{array}{c}\text { Failure load } \\
(\mathrm{KN})\end{array}$ & 80.45111 & 62.86778 & 80.38178 & 127.9688 & 67.97583 & 146.7759 & 27.96875 & -32.0242 & 46.7759 \\
\hline GBG5-2 & $\begin{array}{l}\text { Midspan } \\
\text { Deflection } \\
(\mathrm{mm})\end{array}$ & 6.585556 & 12.91778 & 6.628889 & 56.21302 & 177.8947 & 55.12574 & -43.787 & 77.89474 & -44.8743 \\
\hline GBG5-3 & $\begin{array}{c}\text { Bar } \\
\text { diameter } \\
(\mathrm{mm})\end{array}$ & 16 & 16 & 16 & 100 & 100 & 100 & 0 & 0 & 0 \\
\hline GBG5-4 & $\begin{array}{l}\text { Yield } \\
\text { Strength, fy } \\
\text { (MPa) }\end{array}$ & 460 & 460 & 460 & 100 & 100 & 100 & 0 & 0 & 0 \\
\hline GBG5-5 & $\begin{array}{c}\text { Ultimate } \\
\text { Tensile } \\
\text { Strength, fu } \\
\text { (MPa) }\end{array}$ & 632.4056 & 555.3056 & 629.5167 & 111.4123 & 89.75673 & 111.7066 & 11.41226 & -10.2433 & 11.70662 \\
\hline GBG5-6 & Strain Ratio & 1.310556 & 1.157222 & 1.316278 & 112.2936 & 89.05224 & 112.8244 & 12.29364 & -10.9478 & 12.82435 \\
\hline GBG5-7 & $\begin{array}{l}\text { Elongation } \\
(\%)\end{array}$ & 28.55439 & 14.55667 & 26.49628 & 172.0297 & 58.12948 & 170.2198 & 72.02975 & -41.8705 & 70.21979 \\
\hline
\end{tabular}

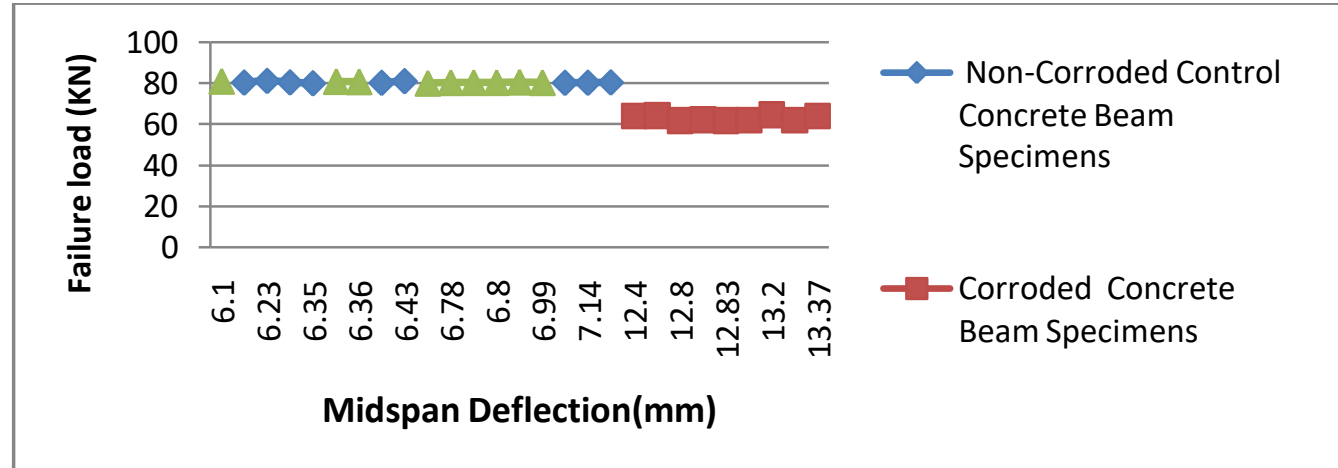

Fig. 1 Failure Load versus Midspan Deflection of Beam Specimens (Non-Corroded, Corroded and Resin Coated Specimens) 


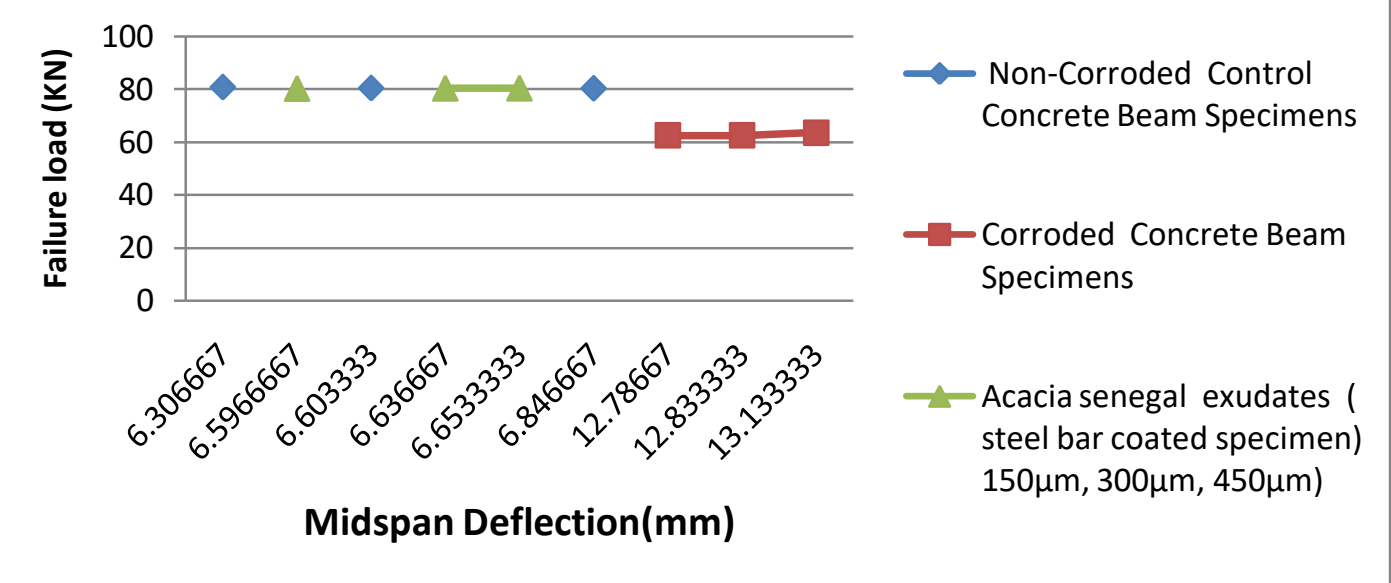

Fig. 2 Average Failure Load versus Midspan Deflection of Beam Specimens (Non-Corroded, Corroded and Resin Coated Specimens)

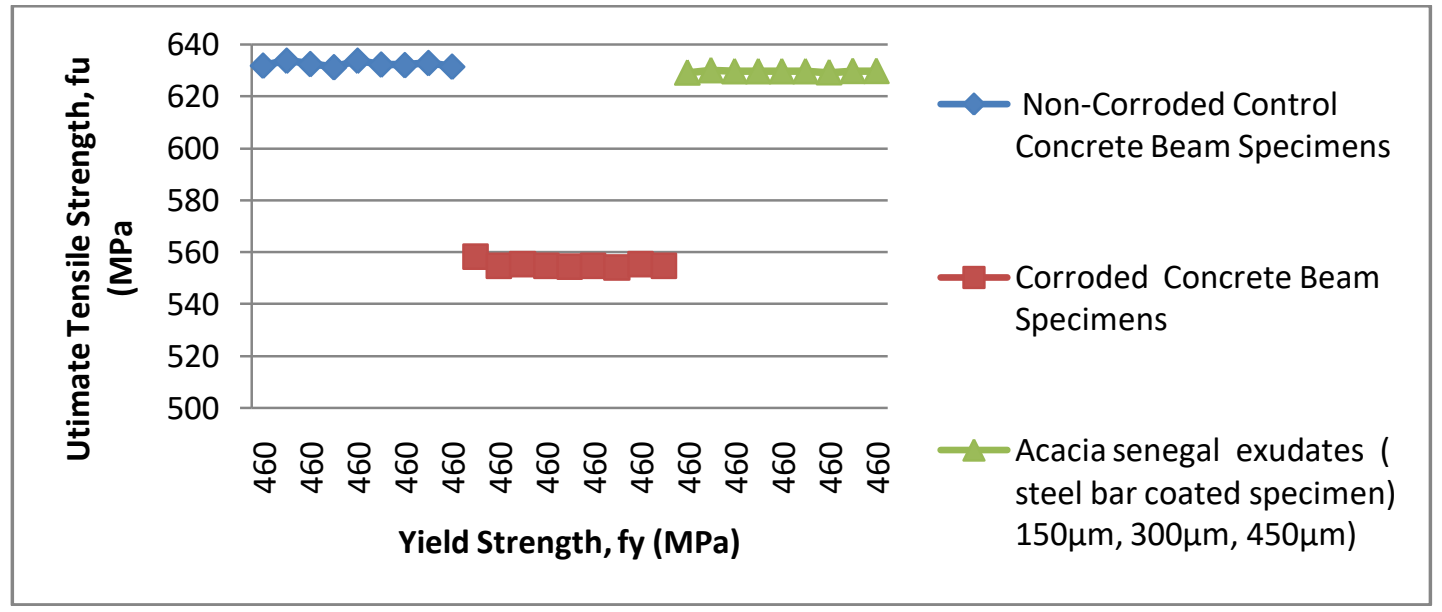

Fig. 3 Ultimate Tensile Strength versus Yield Strength of Beam Specimens (Non-Corroded, Corroded and Resin Coated Specimens)

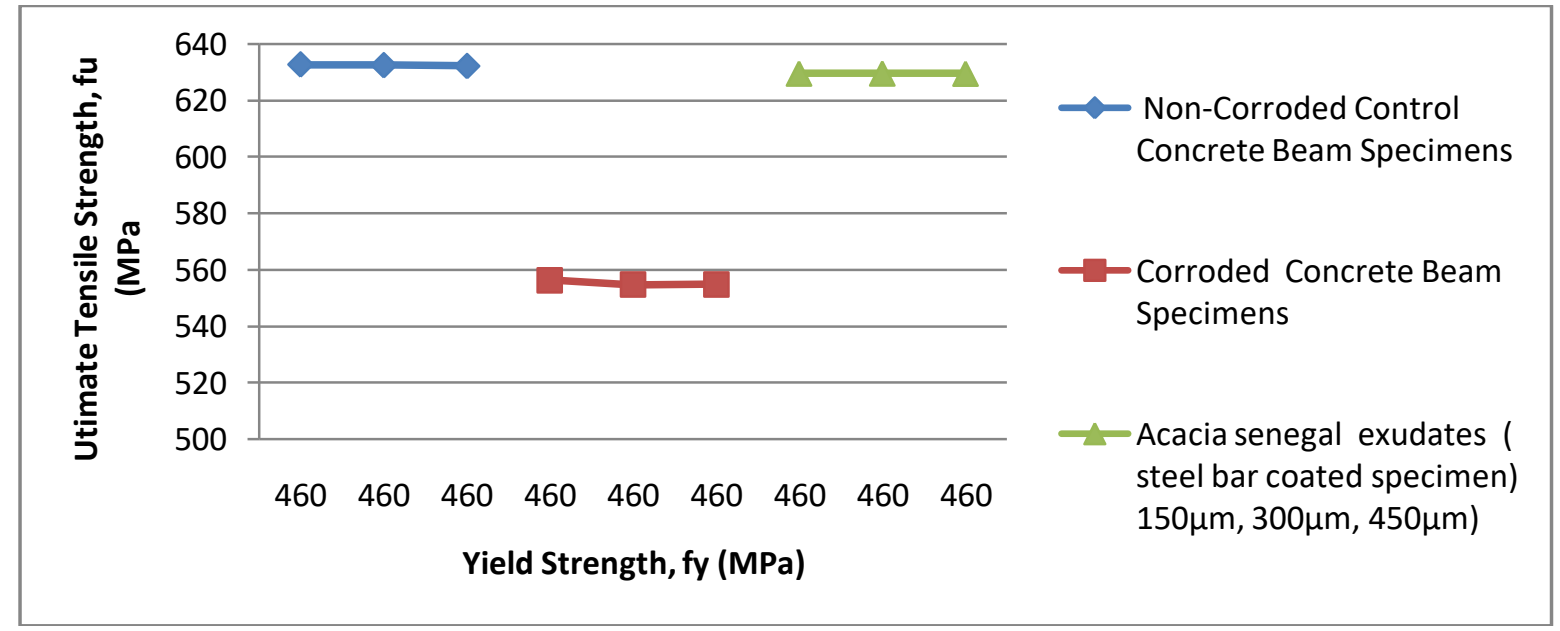

Fig. 4 Average Ultimate Tensile Strength versus Yield Strength of Beam Specimens (Non-Corroded, Corroded and Resin Coated Specimens) 


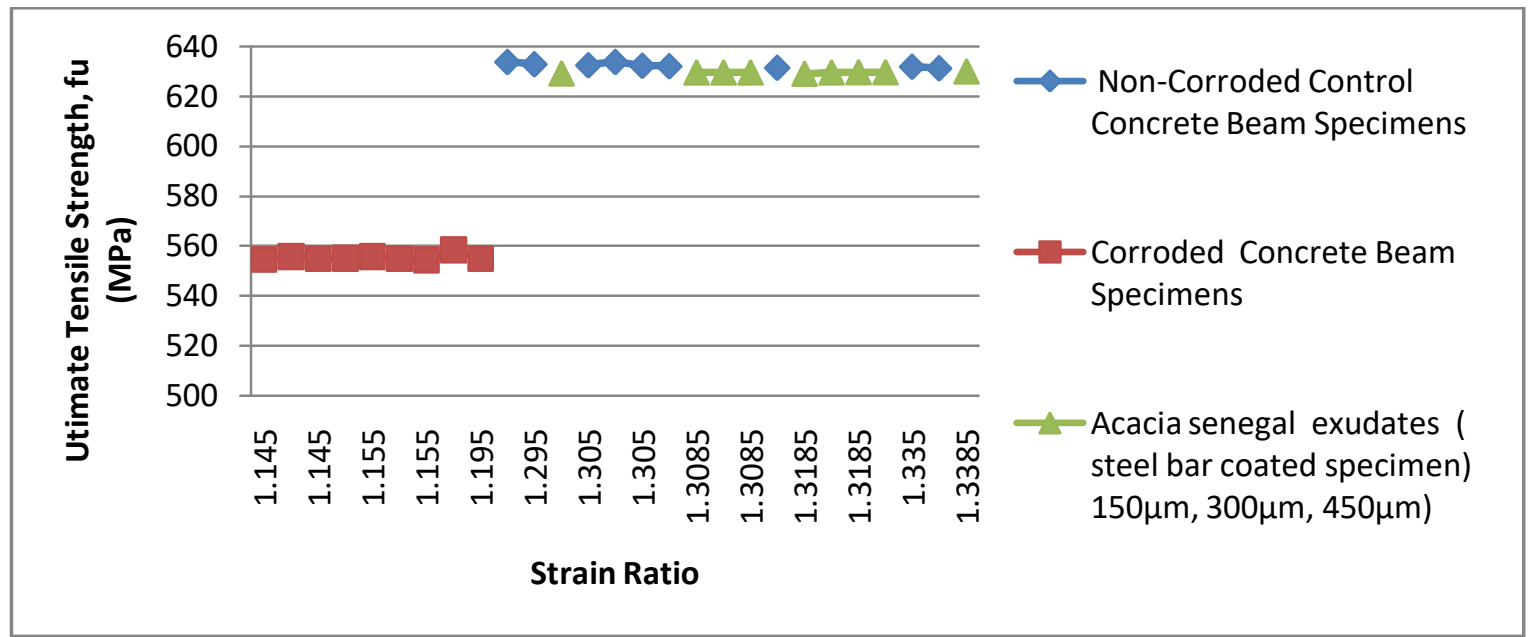

Fig. 5 Ultimate Tensile Strength versus Strain Ratio of Beam Specimens (Non-Corroded, Corroded and Resin Coated Specimens)

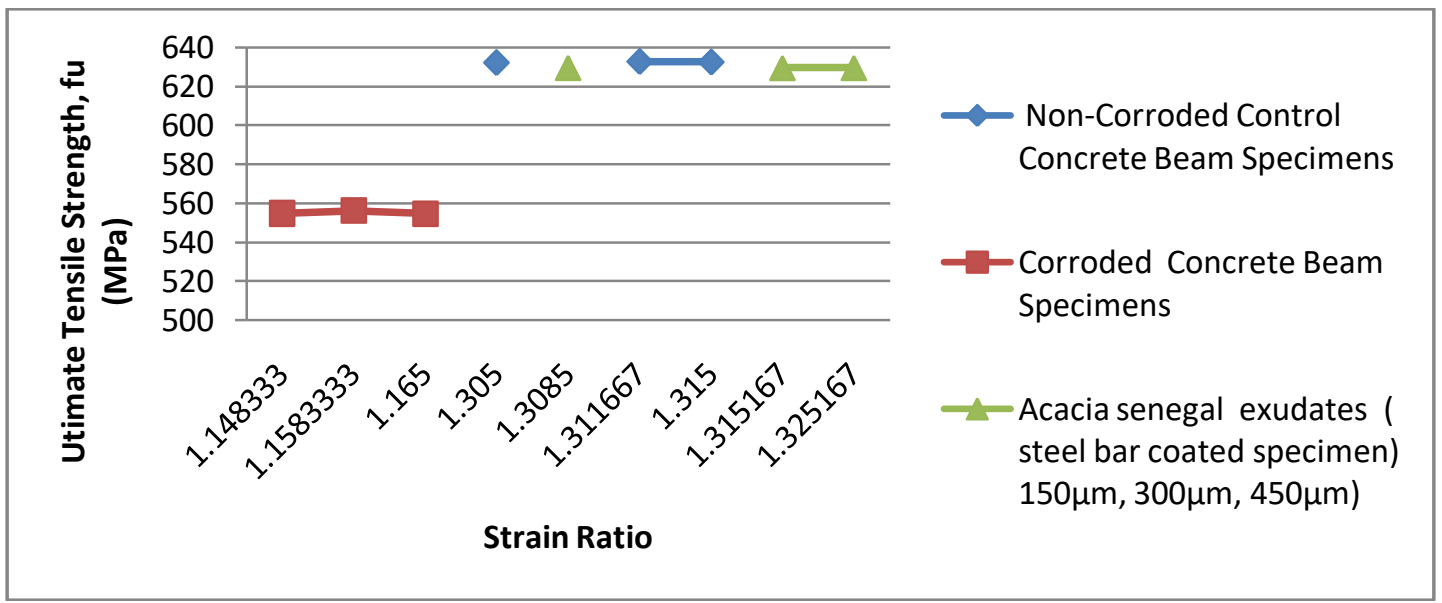

Fig. 6 Average Ultimate Tensile Strength versus Strain Ratio of Beam Specimens (Non-Corroded, Corroded and Resin Coated Specimens)

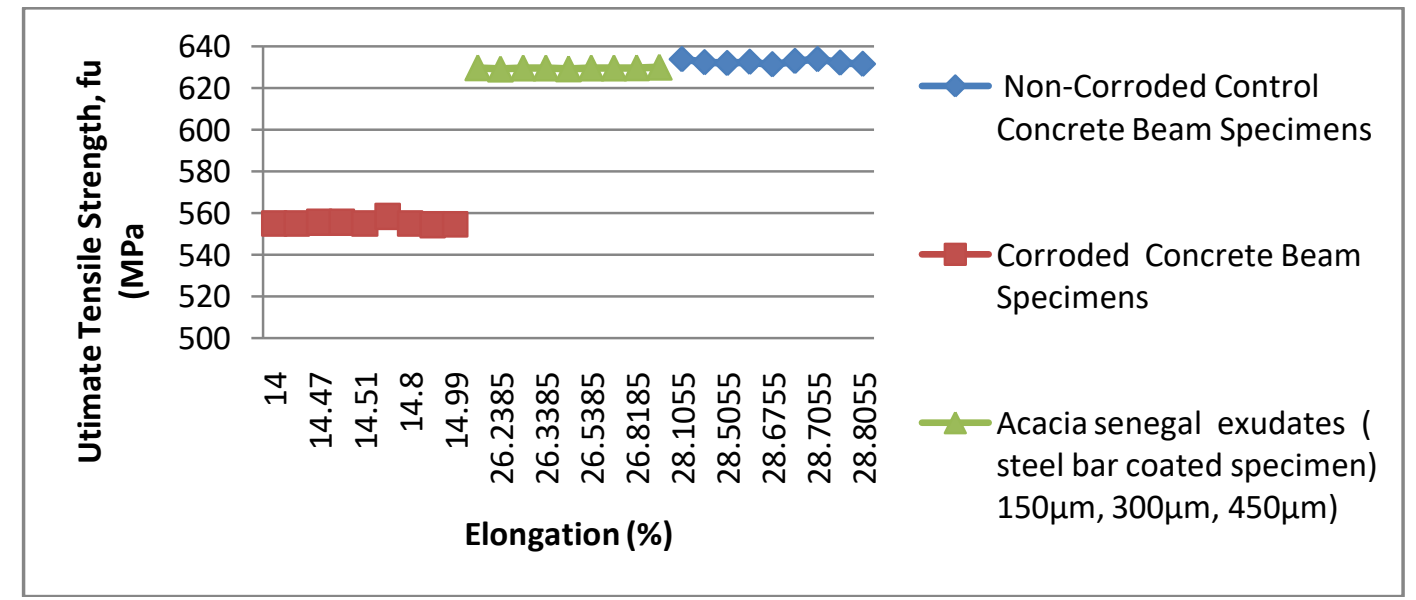

Fig. 7 Ultimate Tensile Strength versus Elongation of Beam Specimens (Non-Corroded, Corroded and Resin Coated Specimens) 


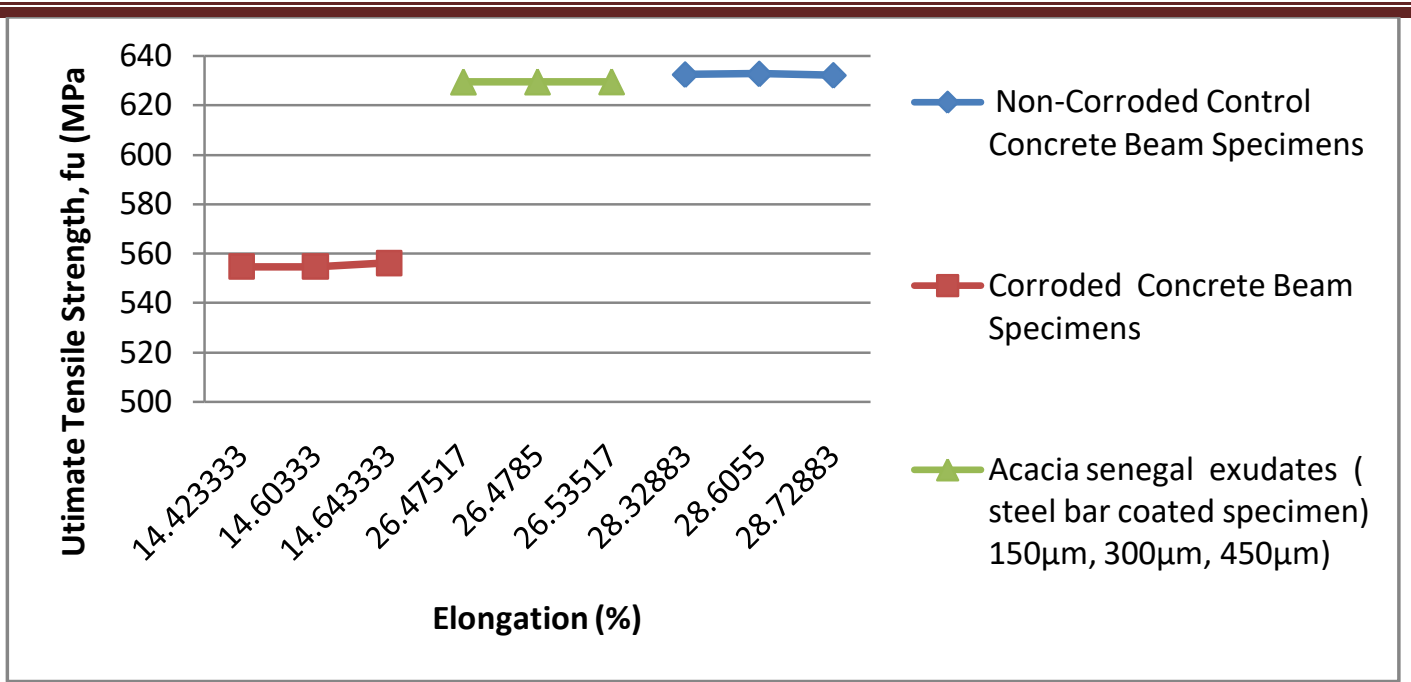

Fig. 8 Average Ultimate Tensile Strength versus Elongation of Beam Specimens (Non-Corroded, Corroded and Resin Coated Specimens)

\subsection{Conclusions}

Experimental results gotten from tables $1-5$ and fig. $1-3$, below were used to draw conclusions for the study as follows:

i. Summarized results of non-corroded over corroded specimens showed that noncorroded (controlled) samples superseded corroded samples properties in low flexural failure load, low midspan - deflection, normal yield strength, high ultimate strength and low strain ratio.

ii. Summarized results of corroded sample showed and exhibited high flexural failure loads over non-corroded and coated specimens, midspan deflection rates are higher to non-corroded and coated specimens, ultimate tensile strength of corroded specimens are all higher to non-corrode and coated specimens.

iii. Overall experimental tests showed that mechanical properties of steel reinforcing steel are adversely affected by corrosion presence.

iv. Summarized results indicated that coated specimens showed low flexural failure load, midspan deflection, strain ratio and ultimate tensile strength.

v. The overall results indicated that tested specimens (coated exudates to reinforcing steels) proved to be inhibitory to corrosion effects.

\section{REFERENCES}

1. Y. G. Du and L. A. Clarkt. Effect of corrosion on ductility of reinforcing bars. Magazine of Concrete Research, vol. 57, no.7, pp. 407- 419, 2005.

2. Almusallam. Effect of degree of corrosion on the properties of reinforcing steel bars.Construction and Building Materials, vol.15, no.8, 361-368, 2001.

3. K. Charles, O. Ishmael,B. M. Akatah, P. P. Akpan. Comparative residual yield strength structural capacity of non-corroded, corroded and inhibited reinforcement embedded in reinforced concrete structure and exposed to severely medium. International Journal of Scientific and Engineering Research, vol. 9, no. 4, pp.1135-1149, 2018.

4. T. E. Ell-Maaddawy, K. Soudki and T.Topper, T. Analytical Model to Predict Nonlinear Flexural Behavior of Corroded Reinforced Concrete Beams. ACI Structural Journal, vol. 102, no. 4, 550-559, 2005.

5. K. Charles, T. T. W. Terence, O. Kelechi, I. S. Okabi. Investigation on comparative flexural residual yield strength capacity of uncoated and coated reinforcement embedded 
in concrete and exposed to corrosive medium. International Journal of Scientific \& Engineering Research, vol. 9, no. 4, pp.655-670, 2018.

6. K. Charles, S. K. Gbinu, K. Ugo. Load carrying capacity of coated reinforcement with exudates of concrete beam in corrosion solution ponding. International Journal of Civil and Structural Engineering Research, vol. 6, no.1, pp: 5-12, 2018.

7. K. Charles, E. I. Ogunjiofor, L. P. Latam. Yield strength capacity of corrosion inhibited (resins / exudates) coated reinforcement embedded in reinforced concrete beam and accelerated in corrosive medium. European International Journal of Science and Technology, vol. 7, no. 3, pp.25-33, 2018.

8. Charles, K., Akpan, P, P., and Gbinu, S, K. Corrosion effects on residual structural capacity of resins / exudates inhibited steel reinforcement flexural beam. European Journal of Engineering Research and Science, vol.3, no. 5, pp. 31-35, 2018.

9. Charles, K., Ogunjiofor, E, I., Letam, L, P. Residual flexural strength of corrosion inhibited resin coated beam in corrosion accelerated media. Global Scientific Journal, vol. 6, no. 5, pp. 84-96, 2018.

10. K. Charles, L. P. Letam, S. K. Gbinu, S. Effect of resins / exudates inhibited steel on the flexural strength of reinforced concrete beam under corrosive environment.International Journal of Advances in Scientific Research and Engineering, vol. 4, no.4, pp. 52-61, 2018.

11. BS 882; - Specification for aggregates from natural sources for concrete, British Standards Institute. London, United Kingdom, 1992.

12. BS EN 196-6; - Methods of testing cement determination of fineness, British Standards Institute. London, United Kingdom, 2010.

13. BS 12390-5; 2005 - Testing Hardened Concrete: Flexural strength test of specimens,British Standards Institute. London, United Kingdom, 2005.

14. BS 12390-5; 2005 - Testing Hardened Concrete: Flexural strength test of specimens,British Standards Institute. London, United Kingdom, 2005

15. W. Otunyo and K. Charles. Effect of corrosion on flexural residual strength and mid-span deflection of steel (coated with resins/exudates of trees) reinforced concrete beams under sodium chloride medium. European International Journal of Science and Technology, vol. 6 no. 7, pp.77-87, 2017. 